\title{
The Ethnic Transference of Feminist Thought Involving Colonialism: A Metacognitive Examination of Multi-Cultural Learning
}

\author{
Shu-Chen Tsai \\ University of Toronto, Toronto, Canada \\ Email: shuchen6688@hotmail.com
}

Received 2 January 2015; accepted 21 January 2015; published 22 January 2015

Copyright (C) 2015 by author and Scientific Research Publishing Inc.

This work is licensed under the Creative Commons Attribution International License (CC BY).

http://creativecommons.org/licenses/by/4.0/

(c) (i) Open Access

\begin{abstract}
An Asian female immigrant to Canada contemplates how Black African feminist concepts are useful in understanding her own feminist history in another racial setting in a different part of the world. Her multi-cultural learning experience yields parallels between Black African feminist thought and her own ethnic cultural experience, prompts ideas about how feminists of all "shades" may achieve greater strength through recognition of commonalities, and creates questions for future research areas of her Asian cultural experience which may be informed and better understood through the insights of Black African feminist thought.
\end{abstract}

\section{Keywords}

Black Feminist Thought, Colonialism, Multi-Cultural Learning, East Asian Feminism, Black Canadian Feminism, Black African Feminism, Black Women

Black feminist thought demonstrates Black women's emerging power as agents of knowledge. By portraying African-American women as self-defined, self-reliant individuals confronting race, gender, and class oppression, Afrocentric feminist thought speaks to the importance that knowledge plays in empowering oppressed people.

[1] (Collins, 2000, p. 39)

\section{Introduction}

University classes involving multiple cultures must always be presented in interesting ways. However, though

How to cite this paper: Tsai, S.C. (2015) The Ethnic Transference of Feminist Thought Involving Colonialism: A Metacognitive Examination of Multi-Cultural Learning. Open Journal of Social Sciences, 3, 94-103.

http://dx.doi.org/10.4236/jss.2015.31011 
being interesting is necessary, it is not sufficient for creating the best classes. The best classes additionally enable students to understand how insights from one culture relate to their own individual cultural histories and to create curiosity platforms for new investigations of issues arising out of the individual student's prior experiences. Black African feminist thought uses knowledge as power to oppose the typical experiences of modern African history-cultures appropriated, land appropriated, individual dignity appropriated, and oppression of females. The following represents the metacognitive learning journey of an Asian woman who encounters these events within the context of black feminism in a university class and then attempts to connect this new knowledge to her own personal lived experiences, the Asian feminist experience, and the future direction of feminism in her adopted nation of Canada. In examining each of the above, the writer builds on her conclusions regarding Black feminist thought thus building platforms for future research regarding her own cultural background.

\section{Two Personal Shadows}

As I transition to Canada from my Asian home culture two shadows have begun to lift. One shadow has been the constant political uncertainty of my home culture. This shadow has lifted as I have become used to the political stability of a nation like Canada. The other shadow is the one that has covered my own personal feminist identity as long as I can remember. It is a quiet and silent shadow with only a vague source, something that causes sadness and personal smallness when you think about it. Feminine inferiority is so much a normal part of my Chinese culture that I seldom consciously recognize it but when I do it seems to cover almost every aspect of my life and seems to insure that my days can never be completely sunny and bright. Nevertheless, the semester I took my course in Black Feminist Thought saw my second shadow begin to lighten.

Both my mother and grandmother are what in my culture we call conservative, traditional women. Their gender view of life as women is very fixed and ridged but it is something that has not been chosen or developed by conscious adoption. It is just something that they have never questioned because it was built into their lives so fully that it was unquestionable.

As I read the assigned novel, "Nervous Conditions" [2] (Dangarembga \& Appiah, 2004) for my Black Feminist Thought course the story of Tambu reminded me so much of my mother's life in my culture. Like Tambu, the central figure of the story, my mother was the oldest girl of five siblings and lived in a rural area and, like Tambu, they grew vegetables and fruits and had a cow for work on the farm and chickens to eat. Because my mother was a girl and was the oldest child it was expected that she would sacrifice her ambitions by helping in the home in order that her other siblings might go to school; and, as an eldest, dutiful daughter, she did. As a result she never went to school. She is now seventy-eight years old, has never read, nor written, nor driven a car.

As strong as my mother and grandmother are they can no more question the gender unfairness of our culture than they could question the air they breathe and, strong as they are, their strength cannot be in resisting or questioning because, for them, there has never been a question to be interrogated or an evil to be resisted. Therefore, though kind and fair as individuals, their strength actually has been channeled to make them allies and supporters of the sexist culture that has limited them so severely. No matter the unfairness of a burden, the only response of my mother and grandmother has always been to endure. Only in an attempted suicide did my grandmother once show the sign of a "passive" resistance. My grandfather had a continuing affair yet the shame of divorce was too great for her to consider though she never spoke to him for the last thirty years of living together. Her one act of active "resistance" in her more than a century of life was aborted when my mother discovered the poison leaves she was attempting to eat.

Even as I write about my maternal ancestors, my words seem too harsh. They have been culturally imprisoned and lived their lives under a shadow of sexism so heavy that they have never noticed the weight and so permanently present that they have never suspected its existence. Though the values that have punished them are now their own values, they have no blame because as the heading quote from [1] Collins (2000) suggests, their education never gave them access to an empowerment to resist the culture.

Unlike my maternal ancestors, I have had such access. I have had the chance to experience reading, school, travel, debate, and analysis. Yet, even so, it has still taken a long time for me to recognize and confront my culture's shadow of gender unfairness. Like Tambu, in the novel "Nervous Conditions" [2] (Dangarembga \& Appiah, 2004), I have only slowly become aware of the ways that life was different for my one brother than for my three sisters and I. Though I have been slow to this recognition, during the semester of my Black Feminist Thought course I made progress. 
Doing graduate assistant research on Black Canadian feminism for my advisor and taking a Black Feminist Thought course that stressed the feminine African colonial experience while I was acclimating to the new environment of freedom of expression and individual dignity of Canada, created a multi-cultural mix conducive for honest examination of my own feminist cultural background. As I took the class I understood that my life experience as an Asian woman made me only an "outside observer/learner” in my Black Feminist Thought class, though I always felt welcomed in the class. However, the experience spoke forcefully, though indirectly, to my Asian life gender experiences. My experience in the course provided much of interest during the course but it also instilled curiosity that looked toward future further research. The following are some of my personal discoveries and conclusions regarding Black feminist thought as well as some of my goals for future research.

\section{A Shared Consciousness of a Great Suffering}

Speaking of Black women, [3] Hooks (2000) writes about the fact that although Black women have suffered the most they have had the least input into feminist thought:

Feminism in the United States has never emerged from the women who are most victimized by sexist oppression; women who are daily beaten down, mentally, physically, and spiritually-women who are powerless to change their condition in life. They are a silent majority (p. 1).

[3] Hooks (2000) explains that of all groups in the United States Black women suffered most saying,

As a group, black women are in an unusual position in this society, for not only are we collectively at the bottom of the occupational ladder, but our overall social status is lower than that of any other group. Occupying such a position, we bear the brunt of sexist, racist and classist oppression (p. 16).

In describing the suffering of Black women, she argues that it exceeds both that of White women and even of Black men, and further argues that when these groups seek equality with White men in the United States it has the effect of further disadvantaging Black women:

White women and black men have it both ways. They can act as oppressor or be oppressed. Black men may be victimized by racism, but sexism allows them to act as exploiters and oppressors of women. White women may be victimized by sexism, but racism enables them to act as exploiters and oppressors of black people... Black male sexism has undermined struggles to eradicate racism just as white female racism undermines feminist struggle. As long as these two groups or any group defines liberation as gaining social equality with ruling class white men, they have a vested interest in the continued exploitation and oppression of others [3] (Hooks, 2000, p. 16).

Though the suffering of Black women must have varied from country to country, the situation in the United States might serve as typical example of their mistreatment and oppression. [4] Russell (1985) describes their situation as follows:

The Black woman began her life of freedom with no vote, no protection, and no equity of any sort. Black women, young and old, were basically on their own. The patterns of exploitation of the Black woman as laborer and breeder were only shaken by the Civil War; by no means were they destroyed. Throughout the late nineteenth and early twentieth century, Black women were severely restricted to the most unskilled, poorly paid, menial work. Virtually no Black woman held a job beyond that of domestic servant or field hand. Keeping house, farming, and bearing and rearing children continued to dominate all aspects of the Black woman's life. The systematic exclusion and routinized oppression of Black females from other areas of employment served as confirmations for the continuation of the servile status of Black women (p. 35).

Maybe the most effective description of the degree of oppression suffered by Black women under slavery in the United States that can be found is the true but terrible description given by a black man regarding the position of the Black women:

Honey, de white man is de ruler of everything as fur as Ah been able tuh find. Maybe its somewhere way off in de ocean where de black man is in power, but we don't know nothing but what we see. So de white man throw down de load and tell de nigger man tuh pick it up. He pick it up because he haf to, but he don't tote it. He hand it to his womanfolks. De nigger woman is de mule uh de world so far as Ah can see [5] 
(Hurston, 1978, p. 29).

\section{Direction of Future Research}

The readings and research of this course have made it very clear that Black women have had terrible situations that are worse than White women and maybe even worse than Black men as well as women of all other colors and other cultures. However, just as it is necessary for White feminists to understand the much worse experience of Black women it seems also necessary for Black feminists to know the oppression experiences of other groups of women. In the future I am interested in researching whether the suffering of Asian women is closer to White or to Black females. I do know that while Black women were being mistreated in America and Canada in the $19^{\text {th }}$ century Chinese women were being made crippled because males thought it was attractive. As described by [6] Goody (1990), the practice involved:

Wrapping a three- to five-year old girl's feet with binding so as to bend the toes under, break the bones and force the back of the foot together. Its purpose was to produce a tiny foot, the "golden lotus", which was three inches long and thought to be both lovely and alluring (p. 25).”

My great grandmother was a victim of this practice. My family still has a picture of her with her very tiny feet. If sexist cruelty such as this was done in my culture, what other unfairness must have existed? I understand that Black women have had the double curse of sexist oppression as well as racial oppression but because I want feminists of all races to be a unified force we must avoid thinking that only one group of women is qualified to speak on oppression or it may destroy the unity we might otherwise have.

All forms of oppression can only be understood from inside the culture that it occurs. In a sense, Asian women have also borne a double curse, one of sexist oppression as well as one that prevents them from voicing resistance to it. According to [7] Woan (2007) Asian women are the least likely of all races of women to report sexual abuse. [8] Triandis \& Suh (2002) report that in collectivist cultures openness is reduced. The closed nature of communications must mean that in Asian societies their collectivist cultures are more likely to wrap their oppression in the protection of silence making it much harder to expose and thus destroy.

\section{An Earlier Time of Justice Destroyed by Colonization}

The characteristics of pre-colonial Africa are difficult to identify with certainty. [9] Reader (1997) notes that it has changed from the Hobbesian view of death and competition to the Rousseau view of the savage with nobility to the Coconut Tree view of relaxed self-sufficiency. The readings in this class frequently had the theme that pre-colonial African culture was more fair and just and less sexist than in Africa since colonization. Buried in the class readings was a constant theme of a desire to return to (or renew) the cultural gender values and feminine dignity that existed in Africa before disruption by its experience with colonialism.

According to [10] Sudarkasa (1986), pre-colonial Africa and especially pre-colonial West Africa created cultural spaces of importance for women that included important family and political leadership positions. In describing the extent of women's political power she notes that from her own research "in this part of the world more than any other, in pre-colonial times women were conspicuous in high places." [10] Sudarkasa (1986) further says that during this period:

Women controlled their own worlds. For example, they had trade and craft guilds, and they spoke on matters of taxation and maintenance of public facilities (such as markets, roads, wells, and streams). They also testified on their own behalf in any court or hearing. Thus, in internal political affairs, women were generally consulted and had channels through which they were represented. External affairs were largely in the hands of men, but in any crisis, such as war, women were always involved: they served minimally as suppliers of rations for troops but in some instances acted as leaders of armies and as financiers of campaigns (p. 91).

Additionally, women in this period were not second class in terms of economics. According to [10] Sudarkasa (1986), they were farmers, traders, and crafts producers and had economic roles that were both public (outside the home) as well as private (inside the home). With some confidence she asserts that "In the economic sphere more than in any other it is easy to show that women's activities were complementary to those of men and that women producers and traders were not subordinate to men (p. 100)." 
Based on such pre-colonial reports, it is no surprise that Black feminists desire to return to a pre-colonial culture and to reverse and limit the effects of colonialism.

\section{Direction of Future Research}

A return to pre-colonial gender fairness seems very important and central to Black feminist thought. It suggests that both the original gender oppression and present oppression of Black women is foreign and external to the present Black culture rather than something that originates from within the Black culture. If this assumption is accurate then correction of the oppression can be achieved not by attacking or changing Black culture but by getting rid of the foreign, external influences that have been mixed into it and returning to the original African values.

[9] Reader (1997) points out that European countries "created the image of Africa that the colonial period bequeathed to the world (p. 612).” However, in considering the oppression of Black women under African colonialism, it should be remembered that there were many different colonizers in many different parts of the world and not only Africans were the victims of colonization. European colonialism was common throughout Asia. Furthermore, frequently the colonial powers (French, British, Portuguese, German, etc.) were the same that colonized Africa.

In my homeland of Taiwan, it was the Japanese that ruled the island from 1895 until 1945 and during this time the Japanese rulers imposed their language and their cultural standards in an attempt to re-create Taiwan in its image. According to [11] Chu \& Lin (2001), Taiwanese were seen by the Japanese as an inferior race, they could not vote, nor serve in the military. Just as Tambu in the book "Nervous Conditions [2] (Dangarembga \& Appiah, 2004)" was forced to think the thoughts and use the language of the colonial power in Africa, my father was required to do similarly in Taiwan. Though my father is no longer alive I still have his books of the Japanese language. He studied Japanese because in order to participate in learning it was required that Taiwanese do it in the Japanese way as well in the Japanese tongue.

Black feminist thought suggests that the Black feminist strength that enabled African women to survive and endure their oppression first in Colonial Africa and later in their adopted countries comes from and is sustained by the dream and goal of once again returning to pre-colonial black cultural. This sustaining dream to return to an earlier cultural fairness stimulates my interest in two aspects of future research.

First, I wonder about indigenous Asian cultures and if there were any past societies where it was common for Asian women to take positions of power and to enjoy positions of social equality with males. If there were such matriarchal societies in Africa it is possible that there may have been Asian ones too. If there have been such matriarchal Asian societies then perhaps an Asian feminist strength based on memories of an earlier, fairer culture can, similar to Black feminism, also serve as the foundation for encouraging an Asian feminism.

Second, I am curious about the gender related methods that were thought to be used by colonial powers to erase the more fair gender practices and values of Black cultures. [12] Peters (1998) suggest that one technique of destroying indigenous African feminist values involved destruction of women's access to land saying that "Settler colonialism in Southern Rhodesia (Zimbabwe) served to compromise the rights of women in Shona and Ndebele societies, as policies that privileged male landowners rather than Shona and Ndebele female farmers (pp. 187-188)." Though not gender specific, [13] Kadar (2002) suggests that in Malaysia "one of the strategies of colonialism has been to wipe out, create amnesia in us about our own traditions..." and that this was partially achieved through the intrusion of colonial law being used to marginalize local indigenous law. Whether through property ownership or control of the legal system or creating of cultural amnesia or other methods, it seems to me that if we understand the methods that were used to erase a group's cultural values then we may be better able to rewrite and revive the original culture and its original values and to resist any continuing attempts to fully erase earlier indigenous values.

\section{Practice of a "Survival" Collectivism}

When I say that Black feminism practices a survival collectivism I do not mean that it is practiced only to achieve survival of individual members. Instead, I mean it is practiced because it is a part of an original black African culture that had the proven effect of allowing survival of a culture as well as its members. It is a collectivism aimed to preserve a culture, not just survival of individual members of a culture.

Perhaps the best definition of collectivism as a general concept is given by [14] Hui \& Triandis (1986) when 
they define it as:

1) concern by a person about the effects of actions or decisions on others; 2) sharing of material benefits; 3) sharing of nonmaterial resources; 4) willingness of the person to accept the opinions and views of others; 5) concern about self-presentation and loss of face; 6) belief in the correspondence of own outcomes with the outcomes of others; and 7) feeling of involvement in and contribution to the lives of others (p. 25).

As described by [15] Wane (2004), collective mothering by Black female graduate students is both an example of Black women's attempt to "survive” budget cuts as well as a reflection of the principles of African collectivism. In describing this African collectivism within the context of her experience with collective mothering as a student, [15] Wane (2004) says "...women have formed mutual groups as a way to deal with the current cutbacks, the social formation of mutual groups reflects the principles of African collectivism (p. 106).” [15] Wane (2004) continues by noting that African collectivism is not limited only to mothering but that: "There are different types of mutual groups seeking different goals, but all are governed by communal needs (p. 107).”

When a group is greatly oppressed it is not surprising to discover that it has developed strong ties among its members to multiply its strength so that neither its members nor its culture will be erased by aggressive dominate groups. [15] Wane (2004) appears to agree with the principle that the goal of feminist African Black collectivism is group survival rather than just individual benefit when she says that within Black feminism there is no expectation of payment to be given or received between members but that: "The only form of remuneration is reciprocity, cohesiveness, and strengthened community ties (p. 107).”

I have often observed that woman of African descent seemed to help each other when they are in a minority position. I have seldom sensed as much cohesion in women of Asian descent. Maybe the influence of Black feminist collective thought is the key to this apparent difference in cohesiveness. Perhaps Asian feminists would benefit by giving it greater examination.

\section{Direction of Future Research}

It appears that the collectivism and community and group emphasis of Black feminism must lead away from individualism and capitalism and toward something like socialism and communism. [16] Healy, et al. (2004), found that "social movements (whether the women's movement, black consciousness or left-wing political parties) appear to foster collectivist values and feed into contemporary trade unionism... (p. 457).”

Asia has seen nations that have moved far in the direction of collectivism. My own background causes me to have an instinctive fear of strong national government collectivism. I have been socialized to believe that collectivism economic systems are now on the reverse trend and individualism and capitalism have been proven superior at least in terms of encouraging human economic productivity. Even the economic improvement in Communist China seems only to have been achieved because it moved away from collectivism towards a more controlled capitalism. I am curious to know how the collectivism of Black feminism can be incorporated into a political system like Canada that protects and allows and partly encourages individualism in economics and private property ownership. My past beliefs suggest that there must be a direct conflict between the two systems of organizing human work efforts but I remain hopeful that this clash of economic systems can be resolved because I value both the collectivism of Black feminism as well as the productivity that individual ownership seems to have produced in my own small Asian country, as well as now in the much larger country of China, and in Canada.

\section{A Strength Provided by Religion/Spirituality}

It seems that part of the reason that Black feminism is so durable is that it draws strength from one of the major social institutions found in all cultures, that of religion. The religion that underlies Black feminism is one that traces to Africa and that is referred to as a type of "spirituality" by some writers and as an "ethic" by others. In discussing the role of this spirituality in African education, [17] Dei (2002) described it as something that is in every human learner that "motivates and provides meaning and hope for learning (p. 38).” [17] Dei (2002) gave greater clearness to his idea of spirituality by noting that it encourages gentleness, humility and compassion, that it is about something beyond the immediate and observable, that it is about individual identification with the source of the universal, and that it is the connector between individual and community and mind, body and soul. [1] Collins (2000) in focusing on the social construction of Black feminist thought and epistemology also identi- 
fied a set of beliefs of that Black feminist practice. Though she refers to these beliefs as an "ethic", it appears that [1] Collins (2000) is, like [17] Dei (2002), describing a type of Black feminist spirituality, and, in fact, she notes:

Since the Black church and the Black family are both woman-centered and Afrocentric institutions, African-American women traditionally have found considerable institutional support for this Dimension of an Afrocentric feminist epistemology in ways that are unique to them (p. 762).

According to [1] Collins (2000) this "ethic" consists of "three interrelated components making up the ethic of caring (p. 767).” The first component is described as individual uniqueness, which, according to [1] Collins (2000), comes from a tradition of African humanism that says that "each individual is thought to be a unique expression of a common spirit, power, or energy expressed by all life (p. 767).” The second component relates to the appropriateness of emotions in dialogue. Finally, the third component "involves developing the capacity for empathy." Taken together these three components are described by [1] Collins (2000) as resembling "the importance that some feminist analysts place on women's inner voice (p. 768.)"

As I combine the descriptions of Dei (2002) and Collins (2000) about empathy, inner voice, gentleness, individual uniqueness as an expression of the common spirit, power, and energy expressed by all life, source of the universal, something beyond the immediate, and the connection between mind, body, and soul, I see a religion or a spirituality even though it is not named as religion. It appears that this common belief system both unites Black feminists and also provides them the appearance of an integrated philosophy of life rather than the appearance of a mere secular social movement.

\section{Direction of Future Research}

This course has challenged me to become more knowledgeable about the relation of my Christian religious beliefs and feminisms in the general and Black feminism in the particular. I am challenged to learn more about the "spirituality" of Black feminism and how it views the Christian religion practiced now both in and outside of Africa. If viewed it as an external "colonial" religion that has been used to control or destroy indigenous African values, then what of Islam? Finally, if there is a "friction" that exists between indigenous Black feminist spirituality and the foreign and external "colonial" Christianity then I am stimulated to examine the nature of a "friction" between the indigenous spirituality of Asian countries that has grown out of its indigenous religions of Buddhism, Confucianism, and Taoism toward the spirituality of Christianity that was imported to Asia from Europe.

\section{Feminist Unity in Resisting Canadian White Patriarchy}

[18] Roberts (1993) suggests that Black women have borne a uniquely severe burden of oppression saying that: "Black women experience various forms of oppression simultaneously, as a complex interaction of race, gender, and class that is more than the sum of its parts (p. 2)."

On the other hand, [19] MacKinnon (1991) argues that

To speak of being treated "as a woman" is to make an empirical statement about reality, to describe the realities of women's situation. In the USA, with parallels in other cultures, women's situation combines unequal pay with allocation to disrespected work, sexual targeting for rape, domestic battering, sexual abuse as children, and systematic sexual harassment; depersonalization, demeaned physical characteristics, use in denigrating entertainment, deprivation of reproductive control, and forced prostitution. To see that these practices are done by men to women is to see these abuses as forming a system, a hierarchy of inequality (p. 15).

The one view suggests that Black women and their oppression is a different matter in substance than that of White women while the other view suggests that women in general are victims of systemic oppressions and that the burden of white and Black women are only differences in degree in a hierarchy of inequality.

According to [20] Mahoney (1993), the [19] MacKinnon (1991) analysis engages in an erroneous "essentialist" and "reductive" analysis in that she is "treating race as additive or incremental to the "essential" oppression of women (p. 217)" and she is asserting that "What is done to white women is a 'floor' for what is done to all women. What is done to women of color is more, added, and worse (p. 219).” The term of essentialism is de- 
fined by [21] Harris (1990) as referring to "the notion that a unitary, essential women’s experience can be isolated and described independently of race, class, sexual orientation, and other realities of experience (p. 585)."

It would appear that the essentialist argument of [19] MacKennon (1991) supports the view of White feminism and it misses the point of Black women's oppression experience. It is like comparing the disappointment of a privileged child's unfair grade of $C$ to the disappointment of Tambu in the novel Nervous Conditions [2] (Dangarembga \& Appiah, 2004) when she was unable to attend school at all. [18] Roberts (1993) makes a similar point when she writes:

There are joys and sorrows that most mothers share... There are also experiences mothers do not share, in part because of race. Most White mothers do not know the pain of raising Black children in a racist society. It is impossible to explain the depth of sorrow felt at the moment a mother realizes she birthed her precious brown baby into a society that regards her child as just another unwanted Black charge. Black mothers must bear the incredible task of guarding their children's identity against innumerable messages that brand them as less than human (pp. 4-5).

In addition to the conflict between the essentialist approach of many White feminists and the more separatist view of Black feminists, [18] Roberts (1993) also makes another point that may serve to divide the two groups of feminists. [18] Roberts (1993) not only attacks patriarchy but she argues that it is one and the same as racism saying: "Racism is patriarchal. Patriarchy is racist. We will not destroy one institution without destroying the other (p. 3)."

It seems that White women might be unwilling to accept this equation of equality between patriarchy and racism because of loyalty to the men of their race. It is one thing for White women to resent White men for the disadvantage imposed upon themselves by White men but it may be another thing to expect White women to blame White men for disadvantage imposed upon other female groups! White female wives of slave owning males in the US were known to respond to the black female victims of their husband's lust with hatred rather than empathy. [22] Northup (2013) writes of one abused black slave woman:

If she was not watchful when about her cabin, or when walking in the yard, a billet of wood or a broken bottle, perhaps, hurled from her mistress' hand, would smite her unexpectedly in the face. The enslaved victim of lust and hate, Patsy had no comfort of her life (p. 142).

I believe that the essentialism approach favored by White women is an invalid approach to feminism and I agree with the [18] Robert's (1993) argument that patriarchy and racism are interconnected and that both must be destroyed to kill either. However, I am not sure that either of these points matter in democratic societies like Canada except in academic discussions. In a country like Canada where policy is determined democratically by majorities, the practical fact is that females in Canada have to become united in numbers to resist (by out-voting) patriarchy values or they will continue simply because they already exist. Although the Black feminist experiences of oppression may have been not just greater in degree but also in nature than White feminists, White feminists have much greater population and social/political power in Canada so Black feminists must join with them and march under their sign even if the sign is the more general (essentialist) one. It may not be fair but Black feminists will have to choose between continuance of patriarchal policies or embracing White feminists as equally or similarly oppressed sisters. The choice may be frustrating for Black feminists but it is really not a very hard one if sexism and racism are to be erased.

\section{Direction of Future Research}

I believe that equality and fairness for women in Canada can only be achieved if women of all races are united to achieve them and that anything that divides the forces of women must be recognized but not emphasized. Since most non-black women's experiences can never enable them to fully understand the oppression of Black feminism I am afraid that unity of women will mean that Black feminists will have to do most of the compromising in order to achieve female unity. I would think that the issue of women's unity in Canada must be an issue that is being worked on. I am curious to know who the different female groups are and I hope that Asian feminists are involved. I am also curious about what strategies feminists of all types have been able to agree on up to now. It seems that there should be some treaty of sisterly agreement that all Canadian women's groups should be able to agree upon that would support some agreed upon level of rights for all Canadian women and some unified strategy. 


\section{Conclusion}

Starting from great ignorance regarding feminisms, I learn that Black women, both as professors and as classmates, can be kind and accepting to a sister that carries a different color, a different cultural experience, and who has feminist perspectives that sometimes agree with and sometimes challenge those of Black feminist thought. I learn of the horrible burdens that have often been connected to being women and being Black. I learn of the spirituality as well the collective values that have strengthen Black women and focused their efforts to oppose patriarchy and return to an earlier period of pre-colonial, African gender equality. I learn that there are potential divisions between separatist Black feminists and essentialists and I have considered the potential of these divisions to weaken all Canadian feminists. I learn that colonialism has left its mark on more than Africa and I consider its effect upon my Asian culture. I have learned that many see my religion of Christianity a tool of oppression used by the colonizing nations. Finally, I learn that there is much that women of all races/cultures need to consider regarding the special struggles of Black women.

\section{References}

[1] Collins, P.H. (2000) Black Feminist thought: Knowledge, Consciousness, and the Politics of Empowerment. Routledge, New York.

[2] Dangarembga, T. (2004) Nervous Conditions: A Novel. Ayebia, Banbury.

[3] Hooks, B. (2000) Feminist Theory: From Margin to Center. South End Press, Cambridge.

[4] Russell, L.M. (1985) Feminist Interpretation of the Bible. Westminster Press, Philadelphia.

[5] Hurston, Z.N. (1937 [1978]) Their Eyes Were Watching God. University of Illinois Press, Chicago.

[6] Goody, J. (1990) The Oriental, the Ancient, and the Primitive: Systems of Marriage and the Family in the Pre-Industrial Societies of Eurasia. Cambridge University Press, Cambridge. http://dx.doi.org/10.1017/CBO9780511621703

[7] Woan, S. (2007) White Sexual Imperialism: A Theory of Asian Feminist Jurisprudence. Washington and Lee Journal of Civil Rights and Social Justice, 14, 275.

[8] Triandis, H.C. and Suh, E.M. (2002) Cultural Influences on Personality. Annual Review of Psychology, 53, $133-160$. http://dx.doi.org/10.1146/annurev.psych.53.100901.135200

[9] Reader, J. (1997) Africa: A Biography of the Continent. Hamish Hamilton, London. http://dx.doi.org/10.2307/3177985

[10] Sudarkasa, N. (1986) The Status of Women in Indigenous African Societies. Feminist Studies, 12, 91-103.

[11] Chu, Y.H. and Lin, J.W. (2001) Political Development in 20th-Century Taiwan: State-Building, Regime Transformation and the Construction of National Identity. The China Quarterly, 165, 102-129. http://dx.doi.org/10.1017/S0009443901000067

[12] Peters, B.L. and Peters, J.E. (1998) Women and Land Tenure Dynamics in Pre-Colonial, Colonial, and Post-Colonial Zimbabwe. Journal of Public and International Affairs, 9, 183-203.

[13] Kader, M. (2002) Colonialism and the Legal Structures of Malaysia. Vinay Lal, Associate Professor of History, UCLA. http://vlal.bol.ucla.edu/multiversity/Right_menu_items/2002conf/Kader_malaysia.htm

[14] Hui, C.H. and Triandis, H.C. (1986) Individualism-Collectivism: A Study of Cross-Cultural Researchers. Journal of Cross-Cultural Psychology, 17, 225-248. http://dx.doi.org/10.1177/0022002186017002006

[15] Wane, N. (2004) Reflections on Mutuality of Mothering: Women, Children and Other Mothering. Journal of the Association for Research on Mothering, 2, 105-116.

[16] Healy, G., Bradley, H. and Mukherjee, N. (2004) Individualism and Collectivism Revisited: A Study of Black and Minority Ethnic Women. Industrial Relations Journal, 35, 451-466. http://dx.doi.org/10.1111/j.1468-2338.2004.00326.x

[17] Dei, G.F. (2002) Spirituality in African Education: Issues, Contentions and Contestations from a Ghanaian Case Study. International Journal of Children's Spirituality, 7, 37-56. http://dx.doi.org/10.1080/13644360220117596

[18] Roberts, D.E. (1993) Racism and Patriarchy in the Meaning of Motherhood. Journal of Gender and the Law, 1, 1-38.

[19] MacKinnon, C. (1991) From Practice to Theory, or What Is a White Woman Anyway. Yale Journal of Law and Feminism, 4, 13-22.

[20] Machoney, M. (1993) From Practice to Theory, or What Is a White Woman Anyway. Yale Journal of Law and Feminism, 5, 217-251.

[21] Harris, A. (1990) Race and Essentialism in Feminist Legal Theory. Stanford Law Review, 42, 581-616. 
http://dx.doi.org/10.2307/1228886

[22] Northup, S. (2013) Twelve Years A Slave (Full Book and Comprehensive Reading Companion). BookCaps Study Guides. Anaheim, CA. 
Scientific Research Publishing (SCIRP) is one of the largest Open Access journal publishers. It is currently publishing more than 200 open access, online, peer-reviewed journals covering a wide range of academic disciplines. SCIRP serves the worldwide academic communities and contributes to the progress and application of science with its publication.

Other selected journals from SCIRP are listed as below. Submit your manuscript to us via either submit@scirp.org or Online Submission Portal.
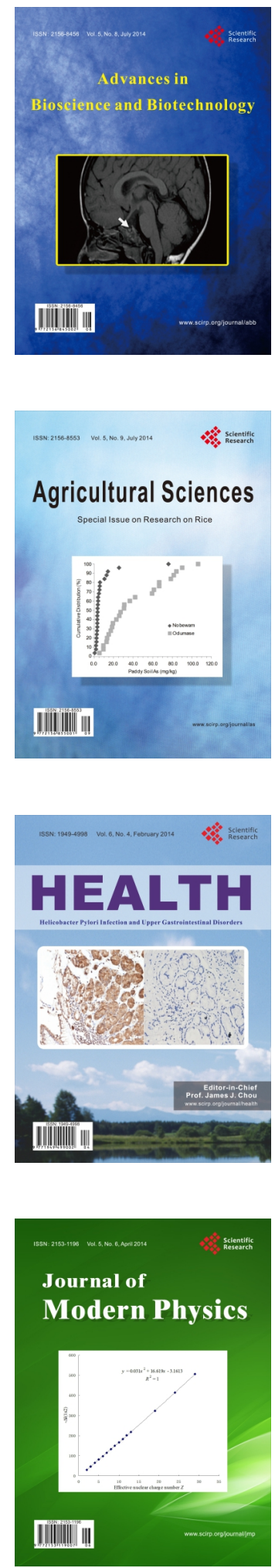
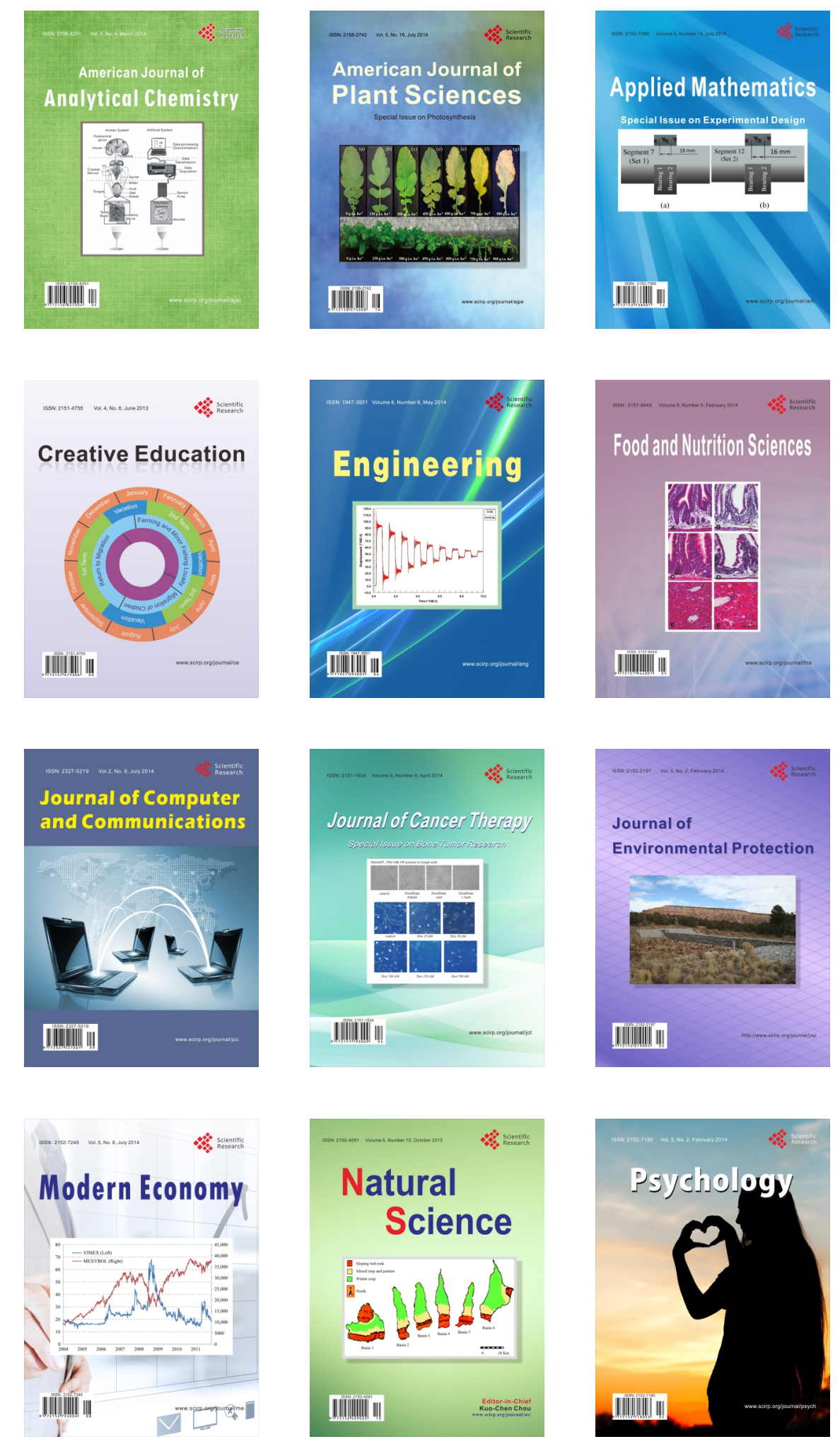